\title{
Pengaruh Model Pembelajaran Kuantum Tipe TANDUR terhadap Minat Belajar Siswa Kelas X
}

\author{
Dya Fatkhiyatur Rohimah ${ }^{1}$, Blasius Suprapta ${ }^{1}$, Dewa Agung Gede Agung ${ }^{1}$ \\ ${ }^{1}$ Pendidikan Sejarah-Universitas Negeri Malang
}

\begin{tabular}{l}
\hline INFO ARTIKEL \\
\hline Riwayat Artikel: \\
Diterima: $17-05-2019$ \\
Disetujui: $16-09-2019$ \\
\hline
\end{tabular}

\section{Kata kunci:}

quantum learning models; interest to learn;

high school student;

model pembelajaran kuantum; minat belajar;

siswa SMA

\begin{abstract}
Education in this globalization era is no longer teacher-centered, but studentcentered. Students must be more active in the learning process, as constructivistic learning theories. This theory bases the learning process on students who construct their own knowledge. So the teacher's role is not too dominant but still provides guidance during the learning process. Through the TANDUR type quantum learning model students, besides building their own knowledge, also explore learning material and associate it with real life. So the learning process will be more fun, interesting, and arouse students' interest in learning.
\end{abstract}

ABSTRAK

\begin{abstract}
Abstrak: Pendidikan di era globalisasi saat ini bukan lagi berorientasi pada guru, namun berfokus kepada siswa. Siswa harus lebih aktif dalam proses pembelajaran, sebagaimana terdapat dalam teori belajar konstruktivistik. Teori ini mendasarkan proses pembelajaran pada siswa yang mengonstruk sendiri pengetahuannya. Sehingga peran guru tidak terlalu dominan tapi tetap memberikan bimbingan selama proses pembelajaran. Melalui model pembelajaran kuantum tipe TANDUR, siswa dapat membangun sendiri pengetahuannya juga mengeksplorasi materi pembelajaran dan mengaitkannya dengan kehidupan sebenarnya. Dengan demikian, proses belajar mengajar akan semakin menyenangkan, menarik serta membangkitkan minat belajar siswa.
\end{abstract}

\author{
Alamat Korespondensi: \\ Dya Fatkhiyatur Rohimah \\ Pendidikan Sejarah \\ Universitas Negeri Malang \\ Jalan Semarang 5 Malang \\ E-mail: dyafr@yahoo.com
}

Pendidikan merupakan suatu hal yang esensial pada proses membangun sebuah negara dan bangsa, sebab tanpa adanya dukungan dari dunia pendidikan bukan tidak mungkin proses pembangunan sebuah Negara atau bangsa dapat berkembang baik. Hasil dari pendidikan yang didapat oleh warga negara diharapkan dapat memacu kualitas dari sumber daya terutama sumber daya manusia di Indonesia secara mandiri maupun komprehensif saat ini atau masa yang akan datang. Sekolah yang dianggap tempat terlaksananya aktivitas belajar diharapkan bias melaksanakan perubahan serta perbaikan supaya anggapan yang salah dapat diubah. Pendidikan dianggap berhasil apabila terdapat perubahan ke arah yang lebih baik pada individu, baik yang berasal dari sisi keterampilan, pengetahuan, sikap, serta perilaku yang dapat diterapkan pada kehidupan di masyarakat melalui aktivitas pembelajaran di sekolah (Rohim, 2016).

Secara umum, Belajar didefinisikan sebagai proses pendewasaan diri siswa, tujuan ini akan dapat terlaksana melewati interaksi yang aktif antara siswa serta guru sebagai yang melakukan kegiatan belajar mengajar. Selain itu, belajar juga membutuhkan keikutsertaan kerja secara aktif siswa. Maka semakin jelas jika aktivitas pembelajaran bukan aktivitas dari satu pihak siswa maupun guru saja. Kesuksesan proses belajar begitu tergantung dengan keikutsertaan yang komprehensif di antara siswa di bawah arahan dari guru (Lestari, 2014). Aktivitas pembelajaran merupakan interaksi belajar mengajar antara guru dengan siswa. Belajar adalah pergantian perilaku yang terjadi pada individu siswa untuk menjadi yang lebih baik daripada sebelumnya. Pergantian perilaku yang terjadi adalah sebagai produk dari interaksi antara lingkungan, mulai dari lingkungan eksternal ataupun internal (Ramlah, 2016). Pergantian yang paling baru pada pendidikan yaitu menekankan mengenai pentinya meningkatkan pembelajaran yang memfokuskan pada siswa dalam menyelesaikan permasalahan, pengetahuan, keterampilan menalar, komunikasi serta sikap, sebagai penghitungan hasil berdasarkan yang sudah dipelajari siswa (Nurhasanah \& Sobandi, 2016).

Pembelajaran dapat diartikan sebagai seperangkat kegiatan yang dengan sengaja dimunculkan dengan tujuan untuk mempermudah terjadinya aktivitas pembelajaran. Maknanya, pembelajaran yaitu sebuah aktivitas yang dengan secara sistematis direncanakan serta dilakukan sesuai dengan tata cara tertentu guna melaksanakan pendekaan yang sebaik mungkin dalam mencapai tujuan belajar yang sudah ditentukan (Sutrisno \& Siswanto, 2016). Proses belajar dikatakan efektif apabila terdapat interaksi dua arah dari siswa dan guru, sehingga minat belajar siswa dalam proses pembelajaran sangat diperlukan. Minat dapat 
diartikan sebagai kecondongan individu dalam keterlibatan secara terus-menerus maupun perhatiannya yang berpusat pada objek yang ditetapkan oleh suatu interaksi khusus di antara individu serta objek yang dibuat melalui hubungannya dengan lingkungan. Minat belajar juga bermakna suatu yang membangkitkan motivasi dengan berdasarkan kepada kemauan serta kenyamanan siswa dalam keikutsertaan pada kewajiban dan kemauan guna mendapat wawasan (Ricardo \& Meilani, 2017).

Salah satu dari alternatif yang bisa dipakai ialah dengan menggunakan pendekatan yang lebih menekankan siswa supaya aktif dalam mengonstruksi pengetahuannya sendiri dengan dikaitkan dengan pengalaman nyata sehari-hari (Jatisunda, 2017). Teori konstruktivisme secara pokok merupakan sebuah gagasan yang mendasarkan terhadap aktivitas siswa dalam menginterpretasi, mengorganisasi dan menciptakan pengetahuan (Supardan, 2016). Teori konstruktivisme memberi pandangan bahwa belajar adalah proses aktif dan berkesinambungan yang dilakukan siswa dalam menerapkan informasi dari lingkungan untuk membangun sendiri pemahamnnya. Selain itu, guru tidak hanya memberi wawasan pada siswa, namun siswa juga harus mengonstruk secara mandiri wawasan yang ada pada otaknya untuk selanjutnya menerapkan gagasannya (Jatisunda, 2017).

Melalui teori konstruktivistik siswa bisa berpikir dalam mencari solusi dari sebuah permasalahan, mencari ide serta mengambil ketetapan. Siswa akan semakin mengerti sebab adanya keikutsertaan langsung untuk menemukan wawasan baru, siswa juga semakin menguasai serta dapat menerapkannya pada berbagai kondisi. Di sisi lain, siswa berperan aktif secara langsung sehingga dapat mengingat seluruh konsep. Pandangan konstruktivistik juga menjelaskan jika belajar adalah sebuah proses membentuk wawasan. Proses pembentukan ini harus dilaksanakan seorang yang belajar. Siswa harus aktif melaksanakan aktivitas, berpikir aktif, merangkai konsep, dan memberi makna mengenai perihal yang sedang dipelajari. Proses pembelajaran dengan pendekatan konstruktivisme dilakukan dengan berangkat dari pengetahuan dan pengalaman awal siswa dan selanjutnya mampu membangun pemahamannya sendiri. Prinsip pembelajaran dalam teori konstruktivistik menyebut bahwasanya guru berkontribusi sebagai fasilitator serta mediator yang mendukung agar aktivitas pembelajaran berlangsung dengan lancar (Sumarsih, 2019).

Berdasarkan temuan di lapangan diketahui bahwa minat belajar siswa kurang tampak pada proses pembelajaran, siswa cenderung sekedar menerima hal-hal yang disampaikan dari guru. Dengan demikian, kegiatan pembelajaran lebih sering hanya satu arah, kurang adanya keterlibatan siswa di dalamnya inilah yang membuat suasana belajar terasa monoton. Melalui model pembelajaran kuantum maka proses pembelajarannya akan memunculkan situasi belajar yang efisien serta efektif, melalui cara menerapkan aspek yang terdapat dalam siswa serta lingkungan belajarnya dengan interaksi yang ada di kelas. Model pembelajaran kuantum tipe TANDUR memiliki langkah-langkah sebaai berikut. Pertama, Tumbuhkan: menumbuhkan minat belajar siswa. Kedua, Alami: siwa mengalami langsung hal-hal yang dipelajari. Ketiga, Namai: memberikan konsep dan informasi sesuai tujuan pembelajaran. Keempat, Demonstrasi: siswa diberi kesempatan untuk unjuk kemampuan. Kelima, Ulangi: upaya umpan balik yang dilakukan untuk mereview materi yang telah dipelajari. Model pembelajaran kuantum lebih mengutamakan interaksi serta komunikasi di antara siswa maupun guru sehingga kondisi belajar yang efektif dan efisien (Yahya, 2017).

Model quantum teaching tipe TANDUR ini dapat ditunjang dengan berbagai metode, seperti metode diskusi pada aktivitas belajar mengajar sehingga siswa dapat saling berpendapat, mendengar, dan bekerjasama dalam mempelajari suatu topik tertentu (Fauzi \& Noviartati, 2018). Melalui penerapan model pembelajaran kuantum tipe TANDUR ini sehingga minat belajar siswa semakin lebih tinggi sebab adanya keterlibatan siswa untuk menemukan serta membangun pengetahuannya yang berasal dari bermacam sumber dan mendemonstrasikan hasilnya di kelas. Minat belajar adalah sokongan yang muncul dari individu guna menaikkan aktivitas belajar. Minat belajar dapat semakin berkembang ketika siswa mengetahui manfaat yang akan diperoleh dalam mempelajari suatu hal. Selain itu, minat belajar juga bisa dikonstruk melalui penetapan keinginan yang tinggi serta cocok dengan kemampuan serta bakat siswanya (Lestari, 2014). Minat belajar dapat dikatakan memiliki kontribusi cukup besar dalam kegiatan belajar mengajar. Mata pelajaran yang menarik bagi minat siswa semakin lebih gampang dalam dipahami serta diingat sebab minat mampu meningkatkan aktivitas belajar itu sendiri. Ketika individu memiliki minat yang tinggi dalam suatu hal sehingga akan selalu berupaya dalam melakukannya sampai maksud yang diinginkan dapat dicapai (Hamdani, 2011). Berdasarkan pada pemaparan tersebut maka peneliti hendak melaksanakan penelitian dengan judul Pengaruh Model Pembelajaran Kuantum Tipe TANDUR terhadap Minat Belajar Siswa Kelas X.

\section{METODE}

Penelitian ini termasuk jenis penelitian eksperimen yang berhubungan dengan hubungan sebab akibat atau ketertarikan di antara suatu variabel dengan variabel lain. Namun, peneliti tidak dapat sepenuhnya melakukan kontrol pada seluruh variabel yang diduga berpengaruh tergadap minat belajar serta hasil belajar siswa. Dengan demikian, digunakan desain eksperimen semu. Subjek yang diikutsertakan pada riset ini terdiri dari dua kelas. Kedua kelompok tersebut mendapatkan materi pelajaran yang sama, tetapi akan mendapat perlakuan yang berbeda. Kelas pertama yaitu kelas eksperimen yang mendapat tindakan berupa model kuantum tipe TANDUR. Serta kelas yang kedua menjadi kelas kontrol dengan perlakuan berupa metode konvensional berupa ceramah. Rancangan riset ini dilaksanakan dengan menerapkan metode eksperimen semu (quasi experiment) pada kelas yang sudah ada tanpa merubah komposisi peserta didik. 


\section{Variabel Penelitian}

Variabel dalam riset ini meliputi variabel terikat serta variabel bebas. Variabel bebas merupakan variabel yang akan diukur, dimanipulasi dan diprediksi berpengaruh terhadap variabel terikat. Variabel bebas yang akan diteliti pengaruhnya adalah model kuantum tipe TANDUR bagi kelompok eksperimen dan metode konvensional berupa ceramah bagi kelompok kontrolnya. Untuk variabel terikat yaitu variabel yang diduga keberadaannya mendapat pengaruh dari variabel-variabel bebas. Artinya, variabel terikat inilah yang perubahannya diamati dan diukur oleh pengaruh variabel bebas. Variabel terikat pada riset ini yaitu minat belajar.

\section{Populasi dan Sampel}

Populasi merupakan semua sasaran yang semestinya diteliti serta dalam populasi tersebut pula hasil dari riset diberlakukan. Sampel merupakan salah satu dari populasi yang hendak diteliti dengan intensif (Kasirom, 2010). Populasi pada riset ini yaitu siswa kelas X tahun ajaran 2018/2019 pada MA Assalam Jambewangi Blitar. Kemudian dari populasi yang terdiri enam kelas dipilih kelas untuk kelompok eksperimen dan kelompok kontrol sebagai sampel penelitiannya. Teknik pengambilan sampel ini dilaksanakan melalui jalan purposive sampling, artinya bahwa pemilihan kelompok subjek didasarkan pada sifat-sifat tertentu yang dianggap memiliki keterkaitan yang kuat dengan sifat atau ciri dari populasi yang sudah diketahui pada sebelumnya (Hadi, 2017). Dengan melihat dari data awal hasil belajar siswa maka diperoleh kelas X MIA 2 serta kelas X IIS 2 menjadi sampel penelitian. Selanjutnya, untuk penentuan kelas kontrol dan eksperimen digunakan teknik random. Pada teknik simple random sampling ini, semua subjek dianggap sama dan berpeluang untuk masuk dalam kelas kontrol atau kelas eksperimen (Arikunto, 2013).

\section{Instrumen Penelitian}

Instrumen merupakan alat atau sarana baik berupa tes, angket atau yang lainnya yang digunakan guna mendapat data yang dibutuhkan dalam hal menyelesaikan permasalahan yang hendak dilakukan penelitian untuk mencapai tujuan penelitian. Dalam menyokong proses pengambilan data, peneliti memakai instrumen berupa kuesioner atau juga angket. Kuesioner merupakan beberapa pernyataan yang tertulis digunakan guna mendapat informasi yang berasal dari responden yang artinya laporan yang berkaitan dengan pribadinya maupun hal-hal yang diketahui (Arikunto, 2013). Terdapat 25 pernyataan yang digunakan untuk mengungkapkan variabel minat belajar. Dalam memudahkan dalam mendapat gambaran tentang instrumen yang dipakai pada riset ini (Tabel 1).

Tabel 1. Kisi-kisi Instrumen Variabel Minat Belajar

\begin{tabular}{lll}
\hline Indikator & Sub indikator & Butir \\
\hline \multirow{2}{*}{ Perasaan senang } & Siswa menyukai konten dalam pembelajaran sejarah & $1,2,3$ \\
& Siswa senang dan bersemangat dalam mengikuti proses pembelajaran sejarah & $4,5,6$ \\
\multirow{2}{*}{ Perhatian } & Siswa memiliki fokus/perhatian selama proses pembelajaran sejarah & $7,8,11,12$ \\
& Siswa memberi respon positif selama mengikuti pembelajaran sejarah & 9,10 \\
\multirow{2}{*}{ Aktivitas belajar } & Siswa tertarik dengan aktivitas dalam pembelajaran sejarah & $13,14,17,19$ \\
& Siswa berpatisipasi dalam aktivitas pembelajaran sejarah & $15,16,18$ \\
\multirow{2}{*}{ Kesadaran belajar } & Siswa berupaya belajar sejarah secara mandiri & $20,21,22,24$ \\
& Siswa memiliki tanggung jawab dalam mengerjakan tugas yang diberikan & 23,25 \\
\hline
\end{tabular}

\section{Uji Coba Instrumen}

Validitas merupakan sebuah ukuran yang menggambarkan tingkatan kesahihan atau valid suatu instrumen. Suatu instrumen dianggap valid jika bisa mengungkapkan data yang berasal dari variabel yang diteliti dengan tepat (Arikunto, 2013). Untuk menguji tingkat validitas sebuah instrumen dilaksanakan dengan menerapkan rumus dari korelasi product moment yang dicetuskan oleh Pearson. Pada riset ini, butir pernyataan pada angket dianggap valid jika $r$ hitung $>r$ tabel. Reliabilitas merupakan suatu instrumen yang dipakai sebagai alat untuk mengumpulkan data, sebab instrumennya telah bagus. Reliabel maksudnya adalah bisa dipercaya dan diandalkan. Pengujian reliabilitas instrumen dalam penelitian ini dilaksanakan melalui cara rumus Alpha. Rumus alpha diterapkan guna menemukan reliabilitas dari instrumen yang mempunyai skor 1 dan 0 . Butir pernyataan angket dikatakan reliabel jika nilai Cronbach's Alpha pada semua variabel adalah yang lebih besar dari 0,6. Dalam riset ini, uji validitas dan reliabilitas instrumen dilakukan melalui aplikasi SPSS 21.0. Berikut disajikan hasil uji coba untuk kuesioner minat belajar yang dilakukan pada uji coba pada instrumen (Tabel 2). 
Tabel 2. Hasil Uji Coba Instrumen

\begin{tabular}{|c|c|c|c|c|c|}
\hline No. & r hitung & $r$ tabel & Kriteria & Cronbach's Alpha & Kriteria \\
\hline 1 & 0,613 & & Valid & & \\
\hline 2 & 0,710 & & Valid & & \\
\hline 3 & 0,573 & & Valid & & \\
\hline 4 & 0,684 & & Valid & & \\
\hline 5 & 0,662 & & Valid & & \\
\hline 6 & 0,514 & & Valid & & \\
\hline 7 & 0,629 & & Valid & & \\
\hline 8 & 0,570 & & Valid & & \\
\hline 9 & 0,660 & & Valid & & \\
\hline 10 & 0,443 & & Valid & & \\
\hline 11 & 0,584 & & Valid & & \\
\hline 12 & 0,524 & & Valid & & \\
\hline 13 & 0,423 & 0,361 & Valid & 0,749 & Reliable \\
\hline 14 & 0,444 & & Valid & & \\
\hline 15 & 0,478 & & Valid & & \\
\hline 16 & 0,574 & & Valid & & \\
\hline 17 & 0,545 & & Valid & & \\
\hline 18 & 0,565 & & Valid & & \\
\hline 19 & 0,781 & & Valid & & \\
\hline 20 & 0,566 & & Valid & & \\
\hline 21 & 0,550 & & Valid & & \\
\hline 22 & 0,680 & & Valid & & \\
\hline 23 & 0,596 & & Valid & & \\
\hline 24 & 0,474 & & Valid & & \\
\hline 25 & 0,522 & & Valid & & \\
\hline
\end{tabular}

\section{Analisis Data}

Sebelum dilaksanakan analisis data sehingga harus dilaksanakan uji asumsi terlebih dahulu. Hal ini dimaksudkan guna mencari tahu terpenuhi tidaknya dari syarat-syarat yang dibutuhkan sebuah data supaya bisa dilakukan analisis. Jenis analisis yang digunakan pada riset ini merupakan analisis independen sample $t$ test, yaitu uji normalitas dan uji homogenitas. Uji normalitas dilaksanakan guna melihat apa variabel bebas serta variabel tidak bebas memiliki distribusi normal (Purwoto, 2007). Uji homogenitas merupakan pengujian yang dilaksanakan guna mencari tahu bahwasanya dua maupun lebih dari kelompok data sampel mempunyai varians yang tidak berbeda (homogen). Selanjutnya, data penelitian diolah dengan menggunakan uji independent sample t-test, uji ini dipakai guna mengetahui dua sampel yang tidak memiliki hubungan mempunyai rerata yang tidak sama. Untuk efektivitas dan efisiensi pengolahan data, maka dalam penelitian ini digunakan program komputer SPSS (Statistics Packages for Sosial Science) 21.0 untuk dianalisis selanjutnya dilaksanakan uji hipotesis dengan independent sample t-test. pengujian hipotesis ini dilakukan pada taraf signifikansi 5\%, dan dari hasil pengolahan data inilah yang akan digunakan sebagai dasar interpretasi dan pengambilan keputusan hasil penelitian.

\section{HASIL}

Proses analisis data pada riset ini yaitu dengan menyajikan deskripsi data yang berasal dari hasil penelitiaan berupa deskripsi umum dari setiap variabel yang telah diteliti. Dari sajian deskripsi data tersebut didapat tentang variabel-variabel yang telah diteliti sebagaimana ditunjukkan pada tabel 3.

Tabel 3. Distribusi Frekuensi Minat Belajar Sebelum Perlakuan

\begin{tabular}{ccccccl}
\hline \multirow{2}{*}{ No } & \multirow{2}{*}{ Interval } & \multicolumn{2}{c}{ Kelas Eksperimen } & \multicolumn{2}{c}{ Kelas Kontrol } & \multirow{2}{*}{ Kriteria } \\
\cline { 3 - 6 } & & Frekuensi & Persentase & Frekuensi & Persentase & \\
1 & $60-65$ & 2 & 10,5 & 6 & 35,3 & Rendah \\
2 & $66-71$ & 5 & 26,3 & 6 & 35,3 & Cukup Rendah \\
3 & $72-77$ & 6 & 31,6 & 4 & 23,5 & Sedang \\
4 & $78-83$ & 6 & 31,6 & 1 & 5,9 & Cukup Tinggi \\
5 & $84-89$ & 0 & 0 & 0 & 0 & Tinggi \\
6 & $90-95$ & 0 & 0 & 0 & 0 & Sangat Tinggi \\
\hline
\end{tabular}


Berdasarkan tabel 3 di atas terlihat bahwa persentase minat belajar siswa di kelas eksperimen sebelum perlakuan sebesar 10,5\% memiliki minat belajar rendah, 26,3\% siswa dengan minat belajar cukup rendah, 31,6\% siswa dengan minat belajar kategori sedang, dan 31,6\% siswa dengan minat belajar cukup tinggi. Sementara itu, minat belajar kelas kontrol sebelum diberikan perlakuan terdiri dari 35,3\% siswa termasuk kategori rendah, 35,3\% siswa memiliki minat belajar cukup rendah, 23,5\% siswa dengan kategori minat belajar sedang, dan 5,9\% siswa yang memiliki minat belajar cukup tinggi.

Tabel 4. Distribusi Frekuensi Minat Belajar Sesudah Perlakuan

\begin{tabular}{ccccccl}
\hline \multirow{2}{*}{ No } & Interval & \multicolumn{2}{c}{ Kelas Eksperimen } & \multicolumn{2}{c}{ Kelas Kontrol } & \multirow{2}{*}{ Kateogori } \\
\cline { 3 - 6 } & & Frekuensi & Persentase & Frekuensi & Persentase & \\
\cline { 3 - 6 } 1 & $60-65$ & 0 & 0 & 0 & 0 & Rendah \\
2 & $66-71$ & 0 & 0 & 2 & 11,8 & Cukup Rendah \\
3 & $72-77$ & 0 & 0 & 6 & 35,3 & Sedang \\
4 & $78-83$ & 7 & 36,8 & 8 & 47 & Cukup Tinggi \\
5 & $84-89$ & 9 & 47,4 & 1 & 5,9 & Tinggi \\
6 & $90-95$ & 3 & 15,8 & 0 & 0 & Sangat Tinggi \\
\hline
\end{tabular}

Dari tabel 4 sebagaimana tersebut bisa dilihat minat belajar siswa di kelas eksperimen sesudah perlakuan berupa model pembelajaran kuantum tipe TANDUR. Sebesar 42,1\% siswa memiliki minat belajar yang dapat dikategorikan tinggi, dan 57,9\% siswa dengan minat belajar yang termasuk sangat tinggi. Sedangkan minat belajar siswa pada kelas kontrol sesudah perlakuan menunjukkan sebanyak 5,9\% siswa memiliki minat belajar dengan kategori rendah, 41,2\% siswa dengan minat belajar yang termasuk cukup rendah. $29,4 \%$ siswa tergolong memiliki minat belajar sedang, dan 23,5\% siswa dengan minat belajar cukup tinggi.

Tabel 5. Distribusi Frekuensi Gain Score Minat Belajar

\begin{tabular}{|c|c|c|c|c|c|}
\hline \multirow{2}{*}{ No. } & \multirow{2}{*}{ Interval } & \multicolumn{2}{|c|}{ Kelas Eksperimen } & \multicolumn{2}{|c|}{ Kelas Kontrol } \\
\hline & & Frekuensi & Persentase & Frekuensi & Persentase \\
\hline 1 & $0-7$ & 4 & 21 & 5 & 29,4 \\
\hline 2 & $8-15$ & 9 & 47,4 & 8 & 47,1 \\
\hline 3 & $16-23$ & 6 & 31,6 & 4 & 23,5 \\
\hline 4 & $24-31$ & 0 & 0 & 0 & 0 \\
\hline 5 & $32-39$ & 0 & 0 & 0 & 0 \\
\hline 6 & $40-47$ & 0 & 0 & 0 & 0 \\
\hline
\end{tabular}

Dari tabel 5 di atas diketahui data gain score atau perubahan yang terjadi antara sebelum diberi tindakan dan setelah adanya tindakan. Pada kelas eksperimen di interval 0 - 7 terdapat empat responden (21\%), interval 8-15 terdapat sembilan responden $(47,4 \%)$, dan pada interval 16-23 sebanyak enam responden (31,6\%). Jabaran gain score minat belajar siswa pada kelas kontrol sebelum perlakuan dan sesudah perlakuan menunjukkan bahwa pada interval 0 - 7 terdapat lima responden $(29,4 \%)$, interval 8 - 15 terdapat delapan responden $(47,1)$, dan interval 16-23 sebanyak empat responden $(23,5 \%)$.

\section{Uji Prasyarat}

Sebelum dilaksanakan pengujian hipotesis sehingga perlu dilaksanakan uji prasyarat dahulu. Uji prasyarat yang dilaksanakan dalam penelitian ini yaitu uji normalitas serta uji homogenitas. Untuk uji normalitas dilaksanakan guna mengetahui variabel riset memiliki distribusi normal ataukah tidak. Pada penelitian ini uji normalitas yang dipakai yaitu uji Shapiro-wilk. Dasar untuk penentuan putusan pada uji normalitas ini yaitu apabila nilai sig $>0,05$ dan memiliki distribusi normal. Apabila sig < 0,05 maka data tersebut tidak memiliki distribusi normal, sedangkan uji homogenitas digunakan guna mengetahui data yang dipakai homogen atau tidak. Dalam riset ini, uji homogenitas yang dipakai yaitu uji Levene's. Dasar penentuan putusan pada uji homogenitas yaitu jika sig $>0,05$ data dikatakan homogen. Apabila sig $<0,05$ data dianggap tidak sama. Berikut ini disajikan hasil dari uji homogenitas yang dilaksanakan dengan menerapkan aplikasi SPSS 21.0 for windows.

Tabel 6. Uji Prasyarat Data Minat Belajar

\begin{tabular}{cllll}
\hline & Normalitas & \multicolumn{2}{c}{ Homogenitas } \\
\hline No. & Kelas & Sig & Variabel & Sig \\
\hline 1 & Eksperimen & 0,578 & & \\
2 & Kontrol & 0,308 & & \\
\hline
\end{tabular}


Dari tabel tersebut dapat dilihat nilai signifikansi minat belajar kelas eksperimen 0,578>0,05, sedangkan nilai signifikansi minat belajar pada kelas kontrol 0,308 > 0,05. Dapat dikatakan bahwasanya data dari minat belajar memiliki distribusi yang normal. Untuk uji homogenitas bisa dilihat bahwasanya nilai dari sig minat belajar 0,268 > 0,05, maka dapat diambil simpulan bahwa data yang dipakai adalah homogen.

\section{Uji Hipotesis}

Uji hipotesis dalam riset ini digunakan guna mencari tahu pengaruh dari model pembelajaran kuantum tipe TANDUR terhadap minat belajar dan hasil belajar siswa. Untuk menguji hipotesis yang telah dirumuskan, maka pada penelitian ini digunakan uji independent sample t test melalui bantuan aplikasi SPSS 21.0 for windows. Dasar pengambilan keputusan dalam uji hipotesis ini yaitu apabila nilai dari sig > 0,05 maka menerima Ho serta menolak Ha. Apabila sig $<0,05$ maka menolak Ho serta menerima Ha. Berikut ini perumusan hipotesisnya:

Ho : tidak terdapat pengaruh yang signifikan model pembelajaran kuantum tipe TANDUR terhadap minat belajar siswa. Ha : terdapat pengaruh yang signifikan model pembelajaran kuantum tipe TANDUR terhadap minat belajar siswa.

Tabel 7. Uji Independent Sample T Test

\begin{tabular}{cc}
\hline Kategori & Sig \\
\hline Equal variances assumed & 0,000 \\
\hline
\end{tabular}

Berdasarkan tabel tersebut dapat dilihat bahwasanya nilai dari sig 0,000 $<0,05$. Dengan demikian, diambil keputusan yang mana menolak Ho serta menerima Ha. Hal ini berarti bahwa terdapat pengaruh model pembelajaran kuantum tipe TANDUR terhadap minat belajar.

\section{PEMBAHASAN}

Dari hasil pada uji hipotesis yang sudah dilaksanakan menggambarkan bahwaanya penggunaan model kuantum tipe TANDUR memberi pengaruh signifikan terhadap minat belajar. Pengaruh ini juga tampak terbukti dari rerata minat belajar pada kelompok eksperimen yang lebih banyak daripada rerata minat belajar di kelompok kontrol. Hasil yang ditunjukkan pada uji independent sample t test dimana nilai sig $0,000<0,05$ juga membuktikan bahwa ada perbedaan rerata pada minat belajar siswa di kelompok eksperimen dan kontrol.

Minat belajar dapat dikatakan memiliki kontribusi cukup besar dalam kegiatan belajar mengajar. Mata pelajaran yang menarik untuk minat siswa lebih tidak sulit untuk dipahami serta diingat sebab minat mampu meningkatkan aktivitas dari belajar itu sendiri. Ketika individu memiliki minat tinggi dalam suatu hal, maka akan terus menerus berupaya dalam melakukannya sampai tujuan yang diharapkan dapat dicapai (Hamdani, 2011). Apabila individu telah memiliki minat terhadap suatu objek, maka secara spontan akan muncul perhatian dan kesadaran yang mendalam akan hal tersebut. Seseorang yang memiliki minat dalam belajar maka akan lebih memberikan pusat perhatian dan rasa keingintahuannya yang tinggi ketika proses pembelajaran dalam kegiatan belajar, apabila siswa selalu dapat memusatkan perhatiannya terhadap pelajaran maka dapat mencapai hasil belajar yang tinggi.

Proses belajar yang dilandasi dengan adanya minat belajar membuat siswa merasa puas dengan hasil belajar atau prestasi yang diperolehnya. Demikian juga sebaliknya, apabila siswa belajar tanpa adanya minat maka akan sulit untuk meraih hasil yang maksimal. Dapat disimpulkan bahwa minat belajar juga bermakna kecenderungan seseorang terhadap sesuatu hal. Penerapan model pembelajaran kuantum tipe TANDUR bertujuan guna dapat memperbaiki minat belajar. Hal ini adalah salah satu dari upaya yang dapat dilaksanakan guru sebagai faktor ekstrinsik dalam menumbuhkan minat belajar siswa. Penerapan dari metode pembelajaran modern untuk memberikan materi bisa menstimulus minat belajar lebih tinggi. Guru juga bisa memperbaiki minat siswa melalui cara pemberian peluang untuk siswa dalam mengaplikasikan materi ajar serta mengikutsertakan siswa pada kegiatan belajar mengajar (Heddy, Sinatra, Seli, Taasoobshirazi, \& Mukhopadhyay, 2017).

Hasil dalam riset ini menggambarkan bahwasanya model pembelajaran kuantum tipe TANDUR memberi pengaruh signifikan pada minat belajar sejarah. Hal ini disebabkan oleh adanya hubungan yang dinamis dalam lingkungan belajar dengan interaksi yang berfungsi untuk membangun kerangka landasan belajar (Made, 2009). Melalui model pembelajaran kuantum tipe TANDUR juga mengubah suasana belajar menjadi lebih meriah karena adanya interaksi sehingga dapat memaksimalkan proses pembelajaran. Oleh sebab itu, siswa lebih antusias dan mampu berpartisipasi aktif selama proses pembelajaran.

Model pembelajaran kuantum tipe TANDUR juga memberikan bukti bahwa kelas eksperimen mempunyai minat belajar yang lebih banyak apabila dibanding dengan kelompok kontrol. Tingginya minat belajar pada kelas eksperimen ini dikarenakan penerapan model pembelajaran kuantum tipe TANDUR mampu menarik perhatian siswa sehingga membuat siswa lebih antusias dalam proses pembelajaran sejarah. Pembelajaran kuantum merupakan pembelajaran yang menyediakan proses pembelajaran yang menyenangkan sehingga lebih efektif dalam memberdayakan siswanya. 
Minat belajar memiliki keterkaitan cukup erat dengan perasaan senang. Berdasarkan hasil angket atau kuesioner, minat belajar terlihat bahwa pada indikator perasaan senang siswa di kelompok eksperimen lebih banyak dibanding kelompok kontrol. Adanya perasaan senang ini mampu menyebabkan siswa semakin memperhatikan serta berkonsentrasi saat proses belajar mengajar dilangsungkan. Perasaan senang siswa juga terbukti ketika proses pembelajaran siswa terlihat begitu antusias untuuk menyelesaikan tugas yang diberikan. Demikian pula ketika siswa mengomunikasikan atau menyajikan hasil temuan mereka di depan kelas. Setiap siswa memberikan pendapatnya dan saling memberikan respon atau umpan balik dalam bentuk tanya jawab.

Dasar dari model pembelajaran kuantum tipe TANDUR ini adalah siswa diajak untuk "mengalami”, sehingga proses belajar mengajar bukan sekedar dari satu arah saja yaitu guru. Namun, siswa harus dilibatkan secara aktif dengan cara mengeksplor dan mengonstruk sendiri pengetahuannya dan posisi guru hanya sebagai fasilitator dan pembimbing, bukan lagi satu-satunya sumber. Asas utama model pembelajaran kuantum tipe TANDUR ini yaitu mengantarkan siswa menuju dunia guru serta mengantar dunia guru menuju ke dalam dunia siswa. Salah satu jalan yang dapat dilaksanakan yaitu melalui mengaitkan materi kepada kehidupan nyata. Melalui hal ini maka semakin memudahkan bagi guru untuk masuk ke dunia siswa karena yang dipelajari juga mereka alami pada pengalaman nyata (Made, 2009).

Melalui penerapan model pembelajaran kuantum tipe TANDUR pada kelas eksperimen mampu membuat siswa memiliki kesadaran belajar yang lebih tinggi daripada kelas kontrol. Kesadaran belajar yang dimiliki oleh siswa ini sedikit banyak membuat siswa semakin aktif pada disksusi yang dilakukan di kelas. Hal ini dikarenakan siswa telah membaca dahulu atau telah mempelajari materi yang hendak diberikan sehingga siswa setidaknya sudah memiliki bekal pengetahuan. Kesadaran belajar yang dimiliki oleh siswa secara tidak langsung juga memiliki hubungan atau korelasi yang positif terhadap perhatian siswa tersebut. Semakin adanya kesadaran belajar maka semakin jelas juga perhatian dan juga aktivitas siswa tersebut. Dengan demikian, minat belajar dapat dikatakan memiliki kontribusi besar pada kegiatan belajar mengajar. Mata pelajaran yang menarik bagi minat siswa semakin lebih tidak sulit untuk dipahami serta diingat sebab minat dapat meningkatkan aktivitas belajar mengajar tersebut. Ketika individu memiliki minat tinggi dalam suatu hal, maka selalu berupaya dalam melakukannya sampai tujuan yang dicita-citakan tercapai (Hamdani, 2011).

Berdasarkan hasil penelitian, diketahui bahwa minat belajar siswa pada kelas kontrol lebih sedikit dibanding kelompok eksperimen. Hal ini menggambarkan bahwa perasaan senang siswa tidak cukup tinggi sehingga perhatian dan keterlibatan siswa pada kelas kontrol juga tidak terlalu tampak. Terbukti ketika proses pembelajaran hanya sedikit dari siswa di kelas kontrol yang memperhatikan, mengerjakan tugas, mengajukan pertanyaan, maupun menjawab pertanyaan guru. Pasifnya siswa ketika proses pembelajaran disebabkan oleh rendahnya minat belajar yang dimiliiki, hal tersebut juga membuat hasil belajarnya kurang maksimal. Perbedaan minat belajar antara kelompok eksperimen dan kontrol dikarenakan perbedaan model pembelajaran yang diterapkan pada masing-masing kelas.

\section{SIMPULAN}

Penggunaan model pembelajaran kuantum TANDUR memberikan pengaruh yang signifikan pada minat belajar siswa. Ini terbukti dengan nilai dari sig $0,000<0,05$ yang bermakna bahwa menolak Ho serta menerima Ha. Ketidaksamaan rerata minat belajar di kelompok eksperimen yang menggunakan model kuantum tipe TANDUR juga lebih banyak jika dibanding dengan minat belajar di kelas kontrol yang menerapkan model konvensional. Bukti lain juga tampak pada saat penerapan model pembelajaran tersebut. Pada kelas dengan model pembelajaran kuantum tipe TANDUR siswa terlihat lebih antusias dan berpartisipasi aktif ketika aktivitas belajar mengajar. Berbeda dengan kelompok kontrol yang menerapkan model pembelajaran konvensional, dimana siswanya lebih pasif selama proses pembelajaran.

Berdasarkan hasil penelitian, model pembelajaran kuantum tipe TANDUR dapat dijadikan sebagai salah satu alternatif model pembelajaran, khususnya pada mata pelajaran Sejarah. Pelajaran Sejarah sampai saat ini dianggap tidak menarik, membuat bosan, dan kurang menantang dapat diatasi dengan penerapan model pembelajaran kuantum tipe TANDUR ini. Melalui model pembelajaran ini, interaksi antara siswa dengan guru akan lebih dinamis dan menciptakan kondisi pembelajaran yang nyaman.

Guru juga harus bisa memperhatikan kecenderungan atau karakteristik siswa sehingga guru mampu menggunakan cara yang lebih efisien serta efektif untuk memperbaiki minat belajar. Salah satunya adalah melalui penerapan model pembelajaran kuantum tipe TANDUR ini, guru mengajak siswa lebih interaktif dan berpartisipasi aktif selama proses pembelajaran. Setelah penelitian ini diharapkan adanya berbagai inovasi dalam mengembangkannya.

\section{DAFTAR RUJUKAN}

Arikunto, S. (2013). Prosedur Penelitian: Suatu Pendekatan Praktik (Edisi Revisi). Jakarta: Rineka Cipta.

Fauzi, A. M., \& Noviartati, K. (2018). Pengaruh Model Pembelajaran Quantum Teaching Tipe Tandur Ditinjau dari Motivasi Belajar Siswa. Jurnal Elektronik Pembelajaran Matematika, 5(3), 240-248

Heddy, B. C., Sinatra, G. M., Seli, H., Taasoobshirazi, G., \& Mukhopadhyay, A. (2017). Making Learning Meaningful: Facilitating Interest Development and Transfer in at-risk College Students. Educational Psychology. https://doi.org/10.1080/01443410.2016.1150420

Jatisunda, M. G. (2017). Pengaruh Pendekatan Konstruktivisme terhadap Pemecahan Masalah Matematik Peserta Didik. Jurnal Theorems (The Original of Mathematics), 2(1), 57-66. 
Kasirom, M. (2010). Metodologi Penelitian Kuantitatif-Kualitatif. Malang: UIN Maliki Press.

Lestari, I. (2014). Perngaruh Waktu Belajar dan Minat Belajar. Jurnal Formatif, 3(2), 115-125. https://doi.org/10.30998/Formatif.V3I2.118

Made, W. (2009). Strategi Pembelajaran Inovatif Kontemporer: Suatu Tinjauan Konseptual Operasional. Jakarta: Bumi Aksara.

Nurhasanah, S., \& Sobandi, A. (2016). Minat Belajar sebagai Determinan Hasil Belajar Siswa. Jurnal Pendidikan Manajemen Perkantoran, 1(1), 135-142.

Ramlah. (2016). Penerapan Pendekatan Problem Solving untuk Meningkatkan Kemampuan Siswa pada Materi Operasi Hitung Kelas IV Kartika Banda Aceh. Jurnal Peluang, 4(2), 6-17.

Ricardo \& Meilani, R. I. (2017). Impak Minat dan Motivasi Belajar terhadap Hasil Belajar Siswa. Jurnal Pendidikan Manajemen Perkantoran, 1(1), 79-92. https://doi.org/8108-16281-2

Sirait, E. D. (2016). Pengaruh Minat Belajar terhadap Prestasi Belajar Matematika. Formatif: Jurnal Ilmiah Pendidikan MIPA, 6(1), 35-43. http://journal.lppmunindra.ac.id/index.php/Formatif/article/viewFile/750/659

Sumarsih, S. (2019). Implementasi Teori Pembelajaran Konstruktivistik Dalam Pembelajaran Matakuliah Dasar-Dasar Bisnis. Jurnal Pendidikan Akuntansi Indonesia, 8(1), 54-62. https://doi.org/10.21831/jpai.v8i1.945

Supardan, D. (2016). Teori dan Praktik Pendekatan Konstruktivisme Dalam Pembelajaran. Edunomic, 4(1), 1-12.

Sutrisno, V. L. P., \& Siswanto, B. T. (2016). The Teaching and Learning of Automotive Electrical. Jurnal Pendidikan Vokasi, $6(1), 112-120$.

Yahya, H. (2017). Pengaruh Penerapan Model Pembelajaran Quantum Teaching terhadap Hasil Belajar Biologi Siswa SMP Islam Terpadu Al-Fityan Gowa. Jurnal Biotek, 5(1), 155-166. 